\title{
Best Practices for Community Policing and Crime Prevention in Nigeria
}

\author{
Ugwu, A. N. ${ }^{1}$, Nwaogu, G. A. ${ }^{2}$, Oyebamiji, M. A. ${ }^{3}$ \\ ${ }^{1}$ Department of Adult and Non-Formal Education, Faculty of Education, University of Port Harcourt, Nigeria \\ ${ }^{2}$ Department of Educational Management and Business Studies, Faculty of Education, Federal University Oye-Ekiti, \\ Nigeria \\ ${ }^{3}$ Professor of Adult Education \& Community Development, Department of Adult and Non-Formal Education, \\ University of Port Harcourt, Nigeria \\ Email: ${ }^{1}$ angela.ugwu@uniport.edu.ng, ${ }^{2}$ godwin_nwogu@yahoo.com, ${ }^{3}$ morufu.oyebamiji@uniport.edu.ng
}

\begin{abstract}
Community engagement lies at the core of policing. Therefore, through collaborative efforts, community and police members address crime and disorder using approaches determined to be best practices for their communities. Today, community policing involves a new philosophy of police operations and management; hosting an accountability system involving the entire organisation. Nevertheless, to be effective in preventing crime, Nigerian police must place renewed emphasis on community engagement and practices. Based on this premise, this paper examines the best practices for community policing and crime prevention in Nigeria. The paper began with an introduction which x-rayed community policing as evolving to meet the new expectations that emerge in the 21st Century. The paper further looked into the philosophical principles of community policing, crime prevention, community policing best practices for Nigeria, organisational changes for implementing community policing best practices for Nigeria, and the expected benefits of community policing to Nigerians. The paper concluded that while the ways of implementing community policing may differ in practice in accordance with certain conditions in the communities, it is imperative to know that the basic philosophical principles of community policing should always be adhered to, if the best practices for community policing is to be achieved in Nigeria.
\end{abstract}

Keywords: best practices, community policing, crime prevention

\section{$1 \quad$ Introduction}

The fundamental idea of community policing is that the level of community participation in enhancing safety and social order and in solving community-related crime should be raised as only the police cannot carry out this task on their own. According to Trojanowicz and Bucqueroux (1994) in National Academies of Sciences, Engineering, and Medicine (2018), community policing is a philosophy and organisational strategy in which the emphasis is on cooperation between the citizens and the police. To them, police and the community work in unison to identify problems, set priorities and find solutions to the problems such as crime, drug abuse, fear of crime, social issues, ecological problems and other types of inconvenience and deviation in one's living and working environment. Consequently, Hahn in Fleming (2007) asserts that community policing is characterised by a decentralised organisation whereby police officers obtain legitimacy for their work from the community they serve in addition to the traditional sources of legitimisation (e.g. law agency, the ruling power and other political structures). He further said that in the community policing system, police officers are appraised and awarded for their communication skills (sensitivity to cultural diversity, solutions to problems, mediation in conflicts etc.) and many other kinds of knowledge and skill otherwise excluded from the appraisal models used in traditional and para-militaristic organisational systems.

Community policing is a paradigm shift established at the bedrock of community partnership in creating safe and secure environment for all (https://www.longdom.org/open-access/comm). It is policing whereby the people take active part in their own affairs; the police are not seen as a problem or stranger whose presence stands for danger but as partners in development and those members of the community are co-producers of justice and quality police service https://jis.gov.gm/jcf-strengthening- 
com). This fact indicates the need of involving the community, the local government and the police to work together to tackle crime. One rationale for public involvement is the belief that police alone can neither create nor maintain safe communities. Despite the establishment of community policing and numerous efforts by various police administrations to curtail the level of crime in Nigeria, crime and social disorder still persist in the country. With growing urbanisation and national development, there are signs of complexity and multiplicity of criminal offenses and acts. It then follows that crime has become part of life of people taking different forms with time. In this vent, Demsy and Forts in Darego (2020) viewed community policing as a strategy of crime management that deals with the basic causes of crime with the view of developing and applying longer term solutions to evolving issues through improved police community partnership and communication.

Therefore, in order to encourage the public to share responsibility for enhancing the communities' quality of life and actively support the police in efforts to control and prevent crime, the police must build trust and develop a partnership between themselves and the community members (Cordner, 2005). This partnership needs to be characterised by mutual responsiveness and an equal footing for both partners. To achieve such a partnership, the police must be better integrated into the community and strengthen their legitimacy in the community through policing by consent and improving their services to the community members.

In view of the soaring levels of crime and violence in Nigeria, and the reactive style of traditional policing, the government recently launched a community policing initiative (Campbell and Gavin, 2020). Apart from its proactive nature, community policing is characterised by problem-solving partnership between police and community members and organisational transformation (Bello, Magajji and Jamilu, 2016). This initiative as commendable as it is, needs to be checked and policies put in place so that the police can have a good working relationship with the community members and achieve the intended outcome. This informed the writers' choice of the topic which examined the best practices of community policing and crime prevention in Nigeria.

\section{Community Policing and Crime Control in Nigeria}

Community policing in Nigeria is a very recent practice which gained popularity from the year 2000. Prior to this time, the Nigeria Police force operated on a traditional British semi-military structure of policing that laid emphasis on concentration of powers (Gbenemene \& Adishi, 2017). This practice of traditional policing coupled with the system of federal character made it and still makes it possible for police from one part of Nigeria to work in another part in a country with more than 250 ethnic nationalities who are heterogenous in so many ways. This makes it difficult for the people to trust the police, thereby polarizing the police and the people more. Similarly, the increase in crime occasioned by poverty, bad governance, underdevelopment, unemployment and the rising rate in conflicts and subsequent killings by bandits, boko haram insurgents without much control by the Nigerian police force, kidnapping, armed robbery and other crimes necessitated community policing in Nigeria to enable the community members assist the police in curbing crime. For instance, in 2016, about 2,500 people were killed, 62,000 displaced, 13.7 billion US dollars lost and 47\% internally generated revenue affected in four states - Plateau, Nasarawa, Kaduna and Benue (Agbese, 2017). Similarly, Southern Kaduna alone lost about 880 people, 53 villages destroyed and 18 churches and 1 primary school touched in December, 2015 (Agbese, 2017).

The recent killings of farmers in the South western Nigeria have exposed the inadequacy of Nigerian police in tackling crime and calls for seriousness in involving more citizens in policing their communities. In a similar development, Okikiola, Farmers Association President General reported that 4000 farmers in south-west were killed in 6years (Akinrefon, 2021) and over 30 people kidnapped in the Federal Capital territory (FCT) in just one month (Our Reporters, 2021). These exclude the number of people killed by Boko haram in the North East, bandits in North Central and herders in other parts of the country. Part of the reasons for the high rate of killings may be the inability of the police to protect lives of the citizens and properties due to some reasons that may not be entirely the fault of the police. With about 317,800 police officers protecting about 206 million people (Akpede, 2019), which is grossly inadequate, there is need to involve more citizens in securing their lives and properties. 
Community policing in Nigeria takes different forms ranging from Community Development Associations (CDAs), Peace and security committee, Landlords and Tenants security, neighbourhood watch, Vigilante and recently in the South-west a group called Amotekun was organized to assist in policing the region as the clashes between farmers and herders intensifies.

\section{$3 \quad$ Philosophical Principles of Community Policing}

The philosophical principles of policing in the communities are as follow:

i. Visibility and Accessibility: This requires that police officers be easily approachable by members of the community through creation of a visible and non-threatening presence within the neighbourhood.

ii. Police officers should be aware of the social fabric of their communities. They should cooperate with other administrative agencies to develop social maps of the neighbourhoods to which they are assigned and listed. For instance, vulnerable residents and groups, troublemakers and criminals, crime generators and hot spots, community leaders, types of businesses in the area and social facilities.

iii. Responsiveness: This is an essential philosophical principle of democratic policing. It means that the police respond to the (immediate) needs and concerns of all members of the public and strive to deliver their services promptly, and in an even-handed and unbiased manner, showing empathy to those in need and respect for human rights (Fleming, 2007). Their services should also be tailored to the norms and values of the community and the individual needs of the members of the communities in which the police work.

iv. Requirement for Community Consultation: This is based on the recognition that an introverted police organisation which unilaterally decides what the public needs will not be successful. Consulting, engaging and mobilising the community in the identification of community problems, in analysing the underlying causes of the problems, in setting priorities for actions and implementing these actions are also essential aspects of another distinct strategic feature of community policing. Through consultation, the police demonstrate that the community's concerns, values and advice will be considered (Fridell, 2004). In exchange, the community is desired to provide information, resources and moral support for police activities. In practice, the community should be an active partner with the police in identifying and addressing these issues.

v. Accountability and Transparency: These demand that the police are open to having their activity observed including the behaviour of individual police officers, strategies for police operations, appointment procedures and budget management by a variety of oversight institutions. They also need to voluntarily provide the public with both information and reassurance. The police must be accountable to the law, and accountable and transparent to the public (Goldenberg, 2007). If the police are willing to be transparent regarding their operation, the communities may be much more likely to be supportive when issues arise.

\section{Crime Prevention}

Crime prevention is a plan of action that focuses on individual groups which are at a danger of either becoming suspects or becoming targets of offence. Prevention of crime is to design schedules that deal with the weak people as well as programmes that deal with reducing the chances of committing crime in the short and long-term. Murphy in Nyanya (2017), asserts that preventing crime does not only target the causes of offences, but in the long term, it may do so in the most cost-effective way. Prevention of crime involves all activities that aim to reduce, discourage or prevent the occurrence of certain criminalities, which is changing specific circumstances, altering the situations perceived to have caused them, and introducing a powerful discouragement by means of a strong system of criminal justice (Shiner, Thom \& MacGregor, in Nyanya, 2017).

Community policing is known as involvement in action and it requires collective participation of all persons in communities and at all different levels of government set ups and private sectors. Crime prevention is known to be the expectation, acceptance and appreciation of a criminal situation and creation of a decision to change and diminish it. Crime prevention is an important approach that should 
consider the use of public awareness campaigns as preventative measures to diminish crime. It also means to endeavour reducing, deterring crime and criminal activities. It is applied when government actors make efforts to minimise crime, enforce the law and maintain public law and order (Jonyo and Buchere, 2011).

\section{$5 \quad$ Community Policing Best Practices for Nigeria}

In order to successfully prevent crime and disorder in the communities of Nigeria, the country should adopt the following best practices for community policing.

i. Create fixed geographic neighbourhood areas with permanently assigned police officers: There should be creation of fixed geographic neighbourhood beats. This would allow continuously assigned police officers to focus on the communities, including minority ethnic communities within the designated neighbourhoods with their specific characteristics and concerns and would also demonstrate the officers' feelings of territorial responsibility and enhance their feelings of accountability. Continuing assignment would also allow for mutual recognition and foster communication with the community, as the police officers and the people would have the opportunity to meet each other on a daily basis. In this way the police officers would acquire an adequate understanding of what is important for the community's individuals and groups and would be able to provide the public with information about their activities. The officers assigned to the neighbourhood would act as the direct link between the public and the police agency, other public administration agencies or private organisations that can offer help.

ii. Introduce visible and easily accessible police officers and police facilities in the communities: Communication will only improve if police officers are easily visible and accessible. This can best be achieved if the officers patrol on foot, bicycle, or motorcycle. The creation of sub-stations and mobile stations with community contact points, or high traffic contact points in schools, community centres, transit hubs, or shopping malls, should be staffed with officers who are representative of the communities in the locality as this would facilitate the contacts between the public and the police. The appearance of patrol officers and the atmosphere at police stations should be friendly and non-threatening so that the public will not hesitate to get in contact with them.

iii. Reorientation of patrol activities to emphasise non-emergency servicing: During reorienting patrol activities to non-emergency servicing, the officers conducting foot patrols need to respond to emergency calls and make arrests but should seek other ways to get in non-emergency contact with the public and develop long-term cooperative initiatives with the public to prevent crimes and improve the overall quality of life in the community. Responses to non-emergency phone calls could be organised differently to free more time for long-term problem-solving activities. Instead of routinely sending patrol cars, the police might suggest ways for managing minor concerns without police involvement or to report concerns in alternative ways e.g. sending e-mails, reporting on the telephone or making appointments at police facility.

iv. Community involvement: In addition to maintaining individual contacts, the police should facilitate occasions and forums where they can exchange views with the community on issues of mutual concern. This could be achieved through community advisory boards, joint police-community workshops, public meetings, and police open days. In order to elicit a broad range of views, and to reach as many community members as possible, these public forums should be open to all segments of the community. Specific efforts may need to be made to ensure that groups such as ethnic minorities, women and young people actually become involved in these processes. Such public forums would permit police actions to be discussed (including sharing of personal experiences by police officers and members of the public) and empower the population to engage actively in the issues related to their safety and security. It would also be an opportunity for community members to give input on their concerns and priorities and on how they think their neighbourhood should be policed.

v. Promotion of cooperation: This can also mobilise communities to become actively involved in crime prevention activities and to develop a sense of shared responsibility for enhancing public safety. For instance, involvement of members of the community would be to: enhance informal social control 
through certain activities, create neighbourhood watch groups, development 'Community Service Officer's programmes that will allow uniformed civilians to assist police officers in their nonemergency activities, adopt self-protection measures, and use mediation to settle local disputes (Kondi, 2007).

vi. Introduce pro-active problem-solving approach: Complementing traditional (reactive) enforcement activities, a problem-solving approach to reducing crime and increasing safety is another important aspect of community policing. A key feature of this strategy is the systematic (and ideally computer-aided) analysis of social problems by focusing on recurring patterns of incidents rather than on isolated incidents, treating them as a group of problems; and by determining the underlying causes of crime and disorder. The first thing to be done here is to scan the problems and incidents identified and then analyse. In the next step, solutions are developed and implemented. On a final note, the results of that implementation are assessed. All of these steps are carried out in cooperation between the community and the police. To formalise the problem-solving process, community safety plans can be developed that include a clear statement of the problem; the steps agreed upon to address the problem; the allocation of tasks to individual working group members; objectives and indicators of progress; and regular review dates (Groenewald and Peake, 2004).

vii. Involvement of all government agencies: In problem-solving activities, other government agencies, such as local governments and administrations, courts, the prosecutor's office, as well as social, health and environmental services should also be actively involved as they may offer complementary resources for resolving certain crime and safety related issues.

viii. Involvement of all branches of the police: In order to make a police-public partnership approach to problem-solving successful and sustainable, all branches of the police need to adopt the philosophical principles of community policing and be committed to following the crime preventive, problem-solving and cooperative approach in dealing with the public and with other government agencies as well as with all other police units.

\section{$6 \quad$ Organisational Changes for Implementing Community Policing Best Practices for Nigeria}

Organisational changes required for implementing the community policing best practices mainly involve management issues, internal structures of the police organisation as well as the structures of the community and other government agencies.

\subsection{Changes in Structures and Management Styles within the Police}

i. The police officers assigned to communities need to be flexible enough to adapt their police-public partnership approaches to the specific conditions of the neighbourhoods in which they work since different communities have different values, customs and concerns. As the officers on the beat are most familiar with the community's needs and capacities, they should have the autonomy to act at their own discretion when they put police policy into action (for instance, when initiating contacts, conducting problem-solving and using resources). Devolution and decentralisation of decisionmaking and resource management from the mid-level management to the "front-line" officers are thus particularly important. Decentralisation is closely linked to the transformation of responsibilities of all police officers, with subordinate ranks becoming more self-directing and supervisors and senior ranks assuming a coordinating, guiding and supporting role encouraging front-line officers to be disciplined but creative in their initiative-taking, and ensuring that they have the resources necessary for effective problem-solving (Pettersson, 2005). Police officers as well as their supervisors are accountable to the public, the law and the government for the actions taken by the officers.

ii. Communication within the police should shift from a predominantly top-down approach to a style with more emphasis on a bottom-up approach, where front-line officers transmit the community's concerns and requests to their supervisors and the higher management (Purdy, 2007). This twoway communication should also lead to a collaborative style of decision-making. 
iii. In addition, to devolving responsibilities and enabling the officers to communicate on an equal footing and participate in decision-making with their superiors, empowering police officers to perform community policing in a satisfactory way also requires extensive training and mentoring of the officers. Beyond the traditional technical skills and basic requirements for democratic policing, community policing demands an even broader range of skills, including the ability to communicate (also in the languages of the local communities), to listen to different opinions, to build trust and to mediate in conflicts (Parker, 2007). In addition, it requires ability to develop creative approaches to community concerns, including organising community groups, conducting problem-solving and gathering technology-based information as well as translating general mandates into appropriate action as well as conveying the concerns of the community to the police leadership and other stakeholders. The skills required for community policing should be taught in basic training for cadets and in field training for probationary officers as well as in in-service training for police officers, supervisors and managers.

iv. Police officers, who are adopting the community policing approach and who are willing to learn the new skills, should be considered for incentives such as promotional opportunities or flexible shifts and have their achievements formally recognized (Stoykov, 2007).

v. The performance evaluation must focus on the officers' ability to effectively address community problems and to involve the community in these efforts. For instance, a mixture of quantitative and qualitative criteria measuring (long-term) impacts and outcomes such as the level of the officer's effectiveness in addressing community problems, the level of public satisfaction with the police service, or the level of public cooperation, the sustainability of community projects, and feelings of safety within the community should be introduced (Kondi, 2007).

\subsection{Changes in Structures and Management Styles outside the Police}

i. Empowering the community is as important as empowering the police officers. Police could facilitate the organisation of community meetings and forums, and should educate community members on how they can be actively involved in the problem-solving process. This would include helping them to formulate their own priorities and allocating resources for problem-solving. Empowering community members does not mean making them part of the police or allowing vigilantism. There is also need to sensitize community members to have confidence in the police especially as the public see them as them as corrupt and people that should not be trusted (Gbenemene and Adishi, 2017). This perception played out during the End SARS protest all over the country in October, 2020 where the general public especially the youths protested against police brutality in Nigeria.

ii. Other government agencies must also be made aware of their role and encouraged to take part in the problem-solving approach, and formal structures should be established for smooth cooperation in the interest of avoiding duplication, dividing the labour, assisting each other and developing synergies in the usage of public resources.

\section{$7 \quad$ Expected Benefits of Community Policing to Nigerians}

The public and the police will enjoy a number of benefits if the best practices of community policing are successfully implemented. Therefore, some of the expected benefits are listed below.

i. Communities will be able to convey their concerns to the police as well as become partners in finding solutions tailored to their problems, which, in turn, will lead to improved crime prevention, improved safety and an enhanced perception of safety.

ii. Communities which have come together with the common goal of achieving improved safety, security and livability, will quickly begin to establish long-term relationships, regardless of ethnicity, religious, and political differences. These relationships can also enhance the ability of communities to withstand social problems and pressures that could lead to crime or disorder in the future.

iii. Police-Public Partnership (PPP) can lead to improved relations between the police and the public, thereby increasing public trust, particularly important for the relationships between the police and minority communities that have, in the past, been burdened by conflict. 
iv. Police may receive information or assistance from the communities in disruption of more serious, organised crimes and criminal markets or environment.

v. Good personal relationship of police officer with community members may mobilise law-abiding community members to lend their support or even give direct help, if they see any of the community police officer in danger.

\section{Conclusion}

To promote community policing in Nigerian communities, it is necessary to pay more attention to professional policing, learning skills for solving problems, the development of a sense of belonging to the community, and solving social problems. Also, those who are familiar with the idea of community policing should emphasise police-public partnerships and as well support community members in organising "crime control networks" through which they will be educated in what anyone can do for his/her safety and other kinds of problem solving. Consequently, all stakeholders involved in a community (politicians, police, other government agencies and the public) should actively be committed and support police-public partnerships approach and accept their share of responsibility for sustainability success of community policing in Nigeria.

\section{References}

1. Agbese, D. (2017). Fulani herdsmen? Here are the grim statistics. Guardian Newspaper, Friday, November 3.

2. Akinrefon, D. (2021). 4000 farmers in South west killed in 6 years. Saturday Vanguard, February 13.

3. Akpede, B. (2019). The Nigerian police force and zero accountability on N135 billion VIP police revenue. https://www.dataphyte.com/development/governance-development/the-nigerian-police-force-and-zero...

4. Bello, I., Magajji, S. \& Jamilu, I. M. (2016). An overview of community policing in Nigeria. A paper presented in International conference of Social science and law-Africa. Nigerian Turkish Nile University (NTNU). $11^{\text {th }}-12^{\text {th }}$ May, Abuja, Nigeria. researchgate.net

5. Campbell, J. \& Gavin, M. (2020). Nigeria launches community policing initiative. Council on foreign Relations. https://www.cfr.org

6. Cordner, G. (2005). Community policing: elements and effects. In R. G. Dunham \& G. P. Alpert (Eds.). Critical issues in policing: contemporary readings, 5th ed. Prospect Heights, IL: Waveland, 401-418.

7. Our reporters (2021). Over 30 people kidnapped in FCT in one month. Daily Trust, Saturday $13^{\text {th }}$ February. www.dailytrust.com

8. Darego, T.I. (2020). Community policing strategies for curbing insecurity towards promotion of community development programmes in Rivers and Enugu states. PhD thesis submitted to the department of adult \& nonformal education, university of Port Harcourt. Unpublished

9. Fleming, J. (2007). Experience in implementing community policing in Kosovo. Presentation at OSCE regional police experts meeting on community policing, Skopje, 16-17 October.

10. Fridell, L. (2004). The defining characteristics of community policing. In L. Fridell \& M. A. Wycoff (Eds.). Community policing: the past, present, and future. Washington DC: Casey Foundation.

11. Gbenemene, K \& Adishi, E. (2017). Community policing in Nigeria: Challenges and prospects. International Journal of Social Science and Management Research. 3(3) 2545-5303.

12. Goldenberg, P. G. (2007). Law enforcement officers training programme for combating hate crimes and community policing. Presentation at OSCE Western European regional police experts meeting on community policing, Vienna $11^{\text {th }}-12^{\text {th }}$ June.

13. Groenewald, H. \& Peake, G. (2004). Police reform through community-based policing: Philosophy and guidelines for implementation. New York: International Peace Academy and Safer world.

14. Hahn, P. H. (1998). Emerging criminal justice: three pillars for a proactive justice system. Thousand Oaks: Sage Publications.

15. Jonyo, F. \& Buchere, P. (2011). The changing nature of security and intelligence in Africa: A Theoretical perspective, challenges and reforms. Nairobi: Azinger Ltd.

16. Kondi, T. (2007). Community policing concept and characteristics in the Albanian State police. Presentation at OSCE regional police experts meeting on community policing, Skopje, 16-17 October.

17. Murphy, P. (2000). Management project: Design and presentation. London: Chapman \& Hall. 
18. National Academies of Sciences, Engineering, and Medicine. (2018). Proactive policing: effects on crime and communities. Washington, DC: The National Academies Press.

19. Nyanya, J. T. (2017). Community policing as a strategy to prevent crime in the Zambezi region. An unpublished Master dissertation, University of South Africa.

20. Parker, R. (2007). Implementing community policing in practice: lessons learned and challenges. Presentation at OSCE Western European regional police experts meeting on community policing, Vienna $11^{\text {th }}-12^{\text {th }}$ June.

21. Pettersson, K. (2005). Developing community policing. A food-for-thought-paper at OSCE SPMU, Vienna.

22. Purdy, D. W. (2007). Community policing. Presentation at OSCE Western European regional police experts meeting on community policing, Vienna $11^{\text {th }}-12^{\text {th }}$ June.

23. Shiner, M., Thom, B. \& MacGregor, S. (2004). Exploring community responses to drugs. York: Joseph Rowntree Foundation.

24. Stoykov, M. (2007). Community policing. Presentation at OSCE regional police experts meeting on community policing, Skopje, $16^{\text {th }}-17^{\text {th }}$ October.

25. Trojanowicz, R.C. \& Bucqueroux, B. (1994). Community policing: how to get started. Cincinnati: Anderson Publishing. 